\title{
Intergrative Human Capital Model: Emperical Evidence at the Central Statistics Agency in Aceh Province
}

Fitri Aswin ${ }^{1}$, Ichsan ${ }^{2}$, Naufal Bachri ${ }^{3 *}$

${ }^{1}$ Badan Pusat Statistik Kabupaten Aceh Utara ${ }^{23}$ Universitas Malikussaleh

*Email Corespondent: naufal.bachri@unimal.ac.id

\begin{abstract}
The purpose of this study is to examine the effect of human capital, compensation and work discipline on the performance of the employees for the Central Statistics Agency in Aceh Province and to determine whether the job satisfaction mediates relationships. The data used are primary data by distributing questionnaires to 200 employees for the Central Statistics Agency for Regencies in Aceh Province. The data analysis technique in this study used Structural Equation Modeling (SEM) which was operated through the Amos software. The results showed that human capital, compensation and work discipline can increase job satisfaction and employee performance. Likewise, job satisfaction is direct and significant on employee performance. In addition, the job satisfaction variable also partially mediates the effect of human capital and compensation on performance and the influence of work discipline on the performance of the employees for the Aceh Province Central Statistics Agency. This study shows that the need for human capital in shaping the performance of employees in government.
\end{abstract}

Keywords : human capital, compensation, discipline, satisfaction, performance

\begin{abstract}
Abstrak: Tujuan penelitian ini adalah mengetahui pengaruh modal manusia, kompensasi dan disiplin kerja terhadap kinerja pegawai Badan Pusat Statistik Provinsi Aceh melalui kepuasan kerja. Data yang digunakan adalah data primer dengan menyebarkan kuesioner kepada 200 responden pegawai pada Badan Pusat Statistik Kabupaten/Kota se-Provinsi Aceh. Teknik analisis data dalam penelitian ini menggunakan analisis Structural Equation Modelling (SEM) yang dioperasikan melalui software SEM Amos. Hasil penelitian menunjukkan bahwa modal manusia, kompensasi dan disiplin kerja dapat meningkatkan kepuasan kerja dan kinerja pegawai. Demikian juga, kepuasan kerja berpengaruh secara langsung dan signifkan terhadap kinerja pegawai. Selain itu, variabel kepuasan kerja juga memediasi secara parsial pengaruh modal manusia dan kompensasi terhadap kinerja serta memediasi secara penuh pengaruh disiplin kerja terhadap kinerja pegawai Badan Pusat Statistik Provinsi Aceh. Studi ini menunjukkan bahwa perlunya human capital dalam membentuk kinerja pegawai pada pemerintahan.
\end{abstract}

Keywords : modal manusia, kompensasi, disiplin, kepuasan, kinerja 


\section{INTRODUCTION}

Today, every organization must be able to develop and improve its organization by relying on various ways that are structured in programs to improve the performance of employees. If the performance of employees is generally high, then the goals of the agency/organization can be achieved as planned and vice versa if most or all of the employee's performance is low, the organization is unlikely to achieve the goals that have been planned previously. In order for high employee performance, it is necessary to manage it so that it plays a maximum role in achieving operational goals in an organization. Many factors can affect performance, both from employees personally, and the performance of the organization more broadly. According to Gibson (2003), there are three sets of variables that affect performance, namely individual, organizational and psychological. Manullang (2008) states that the factors that affect performance are education, work discipline and welfare. Performance is also shown on the quality of work and the amount of work completed by employees in completing their duties and responsibilities assigned to show their performance

In terms of the performance of the State Civil Apparatus at the Central Statistics Agency (BPS) for districts/cities throughout the province of Aceh, the authors see and receive information that there has been a development in the performance of employees which is marked by the demands of data users on BPS in presenting data quickly, cheaply and quality. The main problem in improving employee performance and job satisfaction is closely related to the problem of how to increase human capital, provide proper welfare and how to improve work discipline so that it can support the achievement of organizational goals. In addition, there are still weaknesses and shortcomings, especially in the aspect of monitoring the performance of each employee. With the performance allowance or compensation provided, there are still employees who have not worked optimally, so that it has an impact on the performance of the Central Statistics Agency. This error occurs due to a lack of understanding from employees of the benefits provided that it is not a right but a consequence that must be accepted from what is obtained. In addition, the compatibility between the compensation received by each employee still tends not to be based on the knowledge and skills they have. The working conditions and level of difficulty as well as the efforts made by each employee to obtain appropriate compensation are still not clearly visible.

With regard to employee performance, of course, it cannot be separated from responsibilities as employees who are required to work optimally and create new innovations based on the knowledge and ideas possessed by each individual within the Regency/City BPS in Aceh Province. The work given should also follow the SOPs that have been set and still need to be improved. With the implementation of the performance allowance, it is hoped that the servants of the state can carry out their duties and responsibilities properly and increase discipline towards performance. Based on the above problems, the authors want to know the effect of human capital, compensation and work discipline on job satisfaction and employee performance at the Central Statistics Agency in Aceh Province, as well as the role of job satisfaction as a mediating variable in this relationship.

\section{LITERATURE REVIEW}

\section{Human Capital}

The concept of human capital is the ability that a person has since birth or comes from offspring. McGregor (2004) explains that human capital is an important element in improving the economy of a country. Human capital is the same as knowledge, information skills, ideas, and health of a person (Becker, 2002). Human capital is a qualitative dimension of human resources, such as expertise and skills, which will affect the productive ability of these people. These qualitative dimensions are obtained through education, training and health (Farah \& Sari, 2014).

\section{Compensation}

Hariandja (2005), explains that compensation is the overall remuneration received by employees as a result of carrying out work in the organization in the form of money or other forms of salary, wages, bonuses, incentives and other benefits such as health benefits, holiday allowances, meal allowances. , vacation pay and others. Compensation becomes very important for employees because the amount of compensation is a reflection or measure of the value of the employee's work itself. On the other hand, the size of the compensation can affect employee performance, motivation and job satisfaction. Compensation is the role of personnel to provide rewards in return for carrying out the work of the organization (Kadarisman, 2012). If compensation is given appropriately and correctly, employees will get job satisfaction and be motivated to achieve the goals of the organization (Notoatmodjo, 2009).

\section{Work Discipline}

According to Rivai (2009) discipline is a tool used by managers to communicate with employees so that they are willing to change a behavior as well as an effort to increase one's awareness and willingness to obey all company regulations and applicable social norms. A person's willingness to comply with organizational rules and social norms, in doing his job well (Hasibuan, 2013). Anoraga (2002), discipline is a mental and character training so that his actions obey the existing regulations. Simamora (2006), discipline is a procedure that evaluates or reprimands subordinates who violate the rules.

\section{Job satisfaction}


Davis and Newstrom (1994), the concept of job satisfaction is a concept related to individual feelings about pleasure in work. This concept is also related to attitudes and the match between the expectations that arise with the rewards provided by the organization. Handoko (2011), job satisfaction is a pleasant or unpleasant emotional state in which employees view their work. Job satisfaction is a way of feeling his work resulting from an individual's attitude towards work (Suwatno \& Priansa, 2011; Sahem et al., 2021; Yusrizal et al., 2020). Human capital, compensation and work discipline have a significant effect on job satisfaction (Liyas \& Primadi, 2017; Wahyudi, 2019; Akmal \& Tamini, 2015; Farmi et al., 2021).

\section{Employee Performance}

Performance is an organizational achievement achieved through employee performance (Bachri, 2018). Hasibuan (2012) explains that performance is the result of work achieved by a person in carrying out the tasks assigned to him based on skills, experience, sincerity and time. Stating that employee performance is an action, behavior and measurable result where employees are bound or carried out by employees that are related to organizational goals and contribute to organizational goals (Rosita \& Yuniati, 2016). Mangkunegara (2012), employee performance is the result of work obtained by employees in carrying out their responsibilities

The integrated model of human capital was developed from several theories that explain human capital, compensation, work discipline, job satisfaction and performance. The theory is integrated in a comprehensive model after several books and articles have been reviewed. The human capital integration model is as follows:

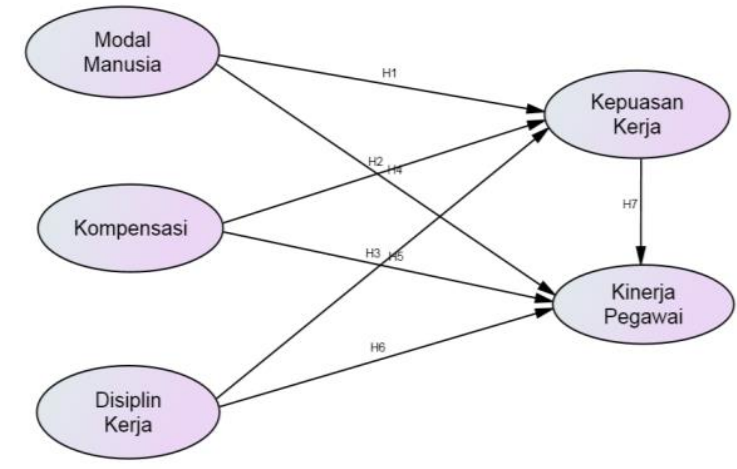

Figure 1. Integrative Human Capital Model

The hypotheses that can be designed are as follows:

H1: Human capital has a significant effect on job satisfaction of the employees of the Central Statistics Agency of Aceh Province.
H2: Compensation has a significant effect on job satisfaction of employees of the Central Statistics Agency of Aceh Province.

H3: Work discipline has a significant effect on job satisfaction of employees of the Central Statistics Agency of Aceh Province.

H4: Human capital has a significant effect on the performance of the employees of the Central Statistics Agency of Aceh Province.

H5: Compensation has a significant effect on the performance of the Central Bureau of Statistics of Aceh Province.

H6: Work discipline has a significant effect on the performance of the employees of the Central Statistics Agency of Aceh Province.

H7: Job satisfaction has a significant effect on the performance of the Central Bureau of Statistics of Aceh Province.

H8: Job satisfaction mediates the effect of human capital on the performance of the employees of the Central Statistics Agency of Aceh Province.

H9: Job satisfaction mediates the effect of compensation on the performance of the Central Bureau of Statistics of Aceh Province.

H10: Job satisfaction mediates the effect of work discipline on the performance of the Central Bureau of Statistics of Aceh Province.

\section{RESEARCH METHODS}

This research was conducted in all offices of the Central Statistics Agency (BPS) Regency/City throughout Aceh Province, totaling 23 units with a total of 452 employees. The sampling technique in this study used a simple random sampling technique. Simple Random Sampling is a simple random primary data collection technique (Bachri, 2019). Primary data was obtained by distributing structured questionnaires to 200 employees of the Central Bureau of Statistics. Data analysis using.

\section{RESULT AND DISCUSSION Characteristics of Respondents}

The following table describes the respondent's data from 
the research. Respondents in this study were employees at the Central Statistics Agency (BPS) of Aceh Province, amounting to 200 people, and after deducting the data from outlier respondents as many as 2 people so that the sample became 198 people.

Table 1: Respondent Profile

\begin{tabular}{lcc}
\hline \multicolumn{1}{c}{ Profile } & $\begin{array}{c}\text { amount } \\
\text { (Orang) }\end{array}$ & $\begin{array}{c}\text { Percentage } \\
(\%)\end{array}$ \\
\hline Gender & & \\
Man & 119 & 60,1 \\
Girl & 79 & 39,9 \\
\hline Age & & \\
20-30 Year & 50 & 25,3 \\
31-40 Year & 104 & 52,5 \\
41-50 Year & 32 & 16,2 \\
$>$ 50 Year & 12 & 6,1 \\
\hline Perkawinan & & \\
Single & 25 & 12,6 \\
Married & 173 & 87,4 \\
\hline Education & & \\
High school & 25 & 12,6 \\
DI/DII/DIII & 18 & 9,1 \\
DIV/S1 & 139 & 70,2 \\
S2/S3 & 16 & 8,1 \\
\hline Source: Processed
\end{tabular}

Source: Processed data (2021)

\section{Confirmatory Factor Analysis (CFA) Test}

The CFA of the Exogenous Construct consists of three latent variables, namely Human Capital which is formed by five indicators, Compensation which is formed by six indicators and Work Discipline which is formed by eight indicators. To see whether the exogenous construct-forming indicators are valid, then a CFA test is performed for each variable. From the results of the Exogenous Construct CFA test, all indicators on the variables in this study have met the standard loading criteria of 0.60 , so all indicators can be said to be valid.

The CFA of the Endogenous Construct consists of two latent variables, namely job satisfaction and employee performance. Where the job satisfaction variable is formed by six indicators and the employee performance variable is also formed by five indicators. To see whether the indicators forming the endogenous construct are valid, then a CFA test is carried out for each variable. To see whether the indicators forming the endogenous construct are valid, then a CFA test is carried out for each variable. From the results of the Exogenous Construct CFA test, all indicators on the variables in this study have met the standard loading criteria of 0.60 , so all indicators can be said to be valid.

\section{Construct Validity test}

In this research, CR, VE, and DV were calculated. The results of these calculations are shown sequentially below:

\begin{tabular}{lccc}
\hline & $\begin{array}{c}\text { Construct } \\
\text { Reliability }\end{array}$ & $\begin{array}{c}\text { Variance } \\
\text { Extracted }\end{array}$ & $\begin{array}{c}\text { Discriminant } \\
\text { Validity }\end{array}$ \\
\hline Human Capital & 0,755 & 0,503 & $>0,500$ \\
\hline Compensation & 0,706 & 0,501 & $>0,500$ \\
\hline Discipline & 0,806 & 0,509 & $>0,500$ \\
\hline Satisfaction & 0,870 & 0,528 & $>0,500$ \\
\hline Performance & 0,784 & 0,505 & $>0,500$ \\
\hline
\end{tabular}

\section{Source: Processed data (2021)}

Based on Table 2, it shows that the construct reliability value generated by all analyzed variables has a value of more than 0.700 . The resulting variance extracted value is also greater than 0.500 . The discrimant validity value of all the variables used has a value of more than 0.500 . These results have shown that all analyzed variables and indicators are suitable for use in this study.

\section{Data Quality}

From the results of the evaluation of the normality of the data, there is a value of cr skewness and cr kurtosis between \pm 2.58 . This means that the data is normally distributed both univariate and multivariate. In this study, the outlier data test used the Mahalanobis Distance test, by comparing the values of $\mathrm{p} 1$ and $\mathrm{p} 2$. According to Ghozali (2014) if the values of $\mathrm{p} 1$ and $\mathrm{p} 2$ are above 0.05 , it indicates that there are no data outliers. In this study, there were 2 outlier data, namely respondents number 18 and 92. Furthermore, after the elimination process, there were no outlier data. Based on the results of the Multicollinearity test in this study, the determinant of the sample covariance matrix is 0.004 meaning that the value is trying to move away from zero, so it can be said that there is no multicollinearity between variables. After fulfilling some of the analyzes above, the data already has a high level of quality.

\section{Structural Model Test}

The description of the structural model aims to see the extent to which the basic model formed in this study meets the goodness of fit criteria so that the model can describe the research phenomenon. The structural model in this study is as follows.

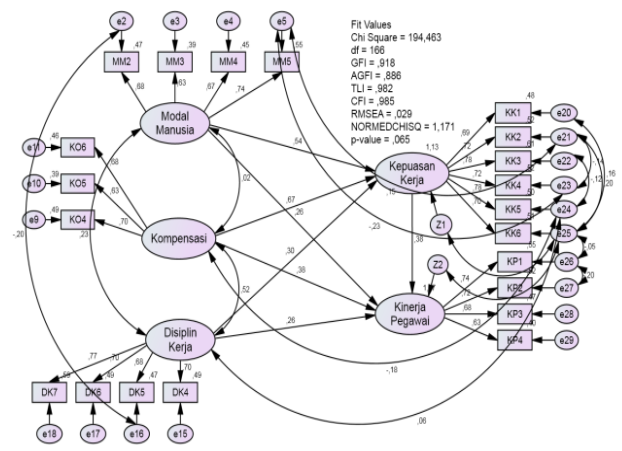

Figure 1: Integrative Human Capital Model

The model above has undergone a modification indice process, because some of the Goodness of Fit (GOF) criteria have not met the requirements. After 
several pairs of errors are connected / covariance, then all criteria can be said to be eligible. The conclusions of the GOF criteria can be seen in the following table.

\begin{tabular}{lcc}
\hline $\begin{array}{c}\text { Goodness of } \\
\text { Fit Index }\end{array}$ & Cut off & $\begin{array}{c}\text { Analysis } \\
\text { Results }\end{array}$ \\
\hline $\mathrm{X}^{2}$-Chi-Square & kecil & 194,463 \\
\hline Probability & $\geq 0,05$ & 0,065 \\
\hline GFI & $\geq 0,85$ & 0,918 \\
\hline AGFI & $\geq 0,85$ & 0,886 \\
\hline TLI & $\geq 0,90$ & 0,982 \\
\hline CFI & $\geq 0,90$ & 0,985 \\
\hline CMIN/DF & $\leq 2$ & 1,171 \\
\hline RMSEA & $\leq 0,08$ & 0,029 \\
\hline
\end{tabular}

Source: Processed data (2021)

The table above shows that all the goodness of fit test criteria have met the requirements. This can be seen by comparing the value of the evaluation results with the cut off value. This cut off value refers to the opinion of Hair et al. (2006). After the above process is fulfilled, then the next step is to look at the coefficient value to test the hypothesis. The following is a table of coefficient values and hypothesis testing.

Table 4: Probability Values and Hypotheses

\begin{tabular}{|c|c|c|c|}
\hline $\begin{array}{l}\text { Hypoth } \\
\text { eses }\end{array}$ & Relationship & $\begin{array}{l}\text { t- } \\
\text { value }\end{array}$ & Probabilitas \\
\hline H1 & $\begin{array}{l}\text { Human capital } \rightarrow \\
\text { job satisfaction }\end{array}$ & $\begin{array}{c}7,5 \\
12\end{array}$ & $0,000 * * *$ \\
\hline $\mathrm{H} 2$ & $\begin{array}{l}\text { Compensation } \\
\rightarrow \text { job satisfaction }\end{array}$ & $\begin{array}{c}7,5 \\
01\end{array}$ & $0,000 * * *$ \\
\hline H3 & $\begin{array}{l}\text { Work discipline } \\
\rightarrow \\
\text { satisfaction }\end{array}$ & $\begin{array}{c}4,4 \\
00\end{array}$ & $0,000 * * *$ \\
\hline $\mathrm{H} 4$ & $\begin{array}{l}\text { Human capital - } \\
\text { job satisfaction }\end{array}$ & $\begin{array}{c}2,8 \\
11\end{array}$ & $0,005 * * *$ \\
\hline H5 & $\begin{array}{l}\text { Compensation } \rightarrow \\
\text { job satisfaction }\end{array}$ & $\begin{array}{c}3,4 \\
61\end{array}$ & $0,000 * * *$ \\
\hline H6 & $\begin{array}{l}\text { Work discipline } \\
\rightarrow \quad \text { employee } \\
\text { performance }\end{array}$ & $\begin{array}{c}2,9 \\
26\end{array}$ & $0,003 * * *$ \\
\hline $\mathrm{H} 7$ & $\begin{array}{l}\text { Job satisfaction - } \\
\text { employee } \\
\text { performance }\end{array}$ & $\begin{array}{c}2,1 \\
12\end{array}$ & $0,035 * *$ \\
\hline H8 & $\begin{array}{l}\text { Human capital } \rightarrow \\
\text { Job satisfaction } \rightarrow \\
\text { employee } \\
\text { performance }\end{array}$ & - & $0,043 * *$ \\
\hline H9 & $\begin{array}{l}\text { Kompensasi } \rightarrow \\
\text { job satisfaction } \\
\rightarrow \text { employee } \\
\text { performance }\end{array}$ & - & $0,042 * *$ \\
\hline H10 & $\begin{array}{l}\text { employee } \\
\text { performance } \rightarrow \text { job } \\
\text { satisfaction } \rightarrow \\
\text { employee }\end{array}$ & - & $0,057 * *$ \\
\hline
\end{tabular}

\begin{tabular}{ll}
\hline \multicolumn{3}{c}{ performance } \\
\hline Note: & \\
$* * *$ & $:$ Significance at $1 \%$ \\
$* *$ & $:$ Significance at $5 \%$ \\
$*$ & $:$ Significance at $10 \%$
\end{tabular}

Hypothesis 1 predicts that human capital has a significant and positive effect on employee job satisfaction at the Central Statistics Agency of Aceh province. The t-value of 7.512 is greater than the t-table of 1.960 , while the probability value of $0.000 * * *$ is smaller than $=0.05$. This means that the better the employee's human capital, the more employees will increase employee job satisfaction. The results of this study are in line with research conducted by Yaya (2016), which states that there is a significant relationship between human capital and job satisfaction caused by increasing the ability of human capital, it will increase job satisfaction and work productivity

Hypothesis 2 predicts that compensation has a significant and positive effect on job satisfaction at the Central Statistics Agency of Aceh province. The t-value of 7.501 is greater than the t-table of 1.960 , while the probability value of $0.000^{* * *}$ is smaller than $=0.05$. This means that the higher the compensation given, the higher the job satisfaction of employees. The results of this study are in line with research conducted by Humairoh (2015) and Rohimah (2013) which found that compensation on employee job satisfaction has a significant and positive effect.

Hypothesis 3 predicts that work discipline has a significant and positive effect on job satisfaction at the Central Statistics Agency of Aceh province. The t-value of 4.400 is greater than the t-table of 1.960 , while the probability value of $0.000^{* * *}$ is smaller than $=0.05$. This means that the high level of work discipline among employees increases employee job satisfaction. The results of this study are in line with the results of Masyjuy's (2005) research; Yunus (2013); \& Mardiono (2014) who concluded that work discipline affects employee job satisfaction. Compliance and obedience to the regulations set by the organization is an important element in government organizations.

Hypothesis 4 predicts that human capital has a significant and positive effect on employee performance at the Central Bureau of Statistics of Aceh Province. The t-value of 2.811 is greater than the t-table of 1.960, while the probability value of $0.005^{* * *}$ is smaller than $=0.05$. This means that good human capital can improve employee performance. The better the potential of the employee, the better the level of employee performance (Ongkorahardjo, 2008; Yani, 2016). The abilities, skills and knowledge possessed by employees are important weapons in improving organizational performance.

Hypothesis 5 predicts that compensation has a significant and positive effect on employee performance 
at the Central Statistics Agency of Aceh Province. The $\mathrm{t}$-value of 3.461 is greater than the t-table of 1.960 , while the probability value of $0.000 * * *$ is smaller than $=0.05$. This means that the higher the compensation provided by the organization, the higher the employee's performance. Compensation in the form of finance is a trigger for enthusiasm for employees and encourages performance in a better direction. This study is in line with research by Faturachman (2013) which concluded that compensation can improve employee performance. compensation is important for the organization itself because compensation programs are a reflection of the organization's efforts to maintain its human resources.

Hypothesis 6 predicts that work discipline has a significant and positive effect on employee performance at the Central Statistics Agency of Aceh Province. The $\mathrm{t}$-value of 2,926 is greater than the t-table of 1.960 , while the probability value of $0.003 * * *$ is smaller than $=0.05$. This means that the better the work discipline, the better the employee's performance. This research is in line with the research of Wanti (2014) which states that work discipline is a determining factor for employee performance.

Hypothesis 7 predicts that job satisfaction has a significant and positive effect on employee performance at the Central Bureau of Statistics of Aceh Province. The t-value of 2.112 is greater than the t-table of 1.960 , while the probability value of $0.035^{* *}$ is smaller than $=$ 0.05 . This means that the more satisfied employees work, the more employee performance will improve. The results of this study are in line with the results of research by Nur (2013) and Umar (2011) who concluded that job satisfaction partially has a positive effect on employee performance.

Hypothesis 8 predicts that human capital has a significant effect on employee performance through job satisfaction at the Central Statistics Agency of Aceh Province. The probability value of 0.043 is smaller than the value of $=0.05$. This means that job satisfaction can mediate well the relationship between human capital and employee performance. The abilities, skills and knowledge possessed by employees can improve employee performance through the level of perceived satisfaction from work.

Hypothesis 9 predicts that compensation has a significant effect on employee performance through job satisfaction at the Central Statistics Agency of Aceh Province. The probability value of 0.042 is smaller than the value of $=0.05$. This means that job satisfaction can mediate well the relationship between compensation and employee performance. Rewards and compensation in the form of maximum financial can increase employee job satisfaction and end up increasing employee performance.

Hypothesis 10 predicts that work discipline has no significant effect on employee performance through job satisfaction at the Central Statistics Agency of Aceh Province. The probability value of 0.057 is greater than the value of $=0.05$. This means that job satisfaction cannot mediate the relationship between work discipline and employee performance. Compliance with existing rules reduces job satisfaction. Employees feel bound by rules that have no impact on performance.

\section{CONCLUSIONS}

Based on the results of the research, discussion and data analysis techniques that the researchers used in this study regarding brand image and online consumer reviews on consumer loyalty, Nature Republic Aloe vera 92\% soothing gel in Sukabumi City, researchers can draw conclusions, namely the results of tests carried out by testing. $\mathrm{T}$ (partial) and also F test (simultaneous), the brand image variable (X1) has a positive effect on the consumer loyalty variable (Y), which means that the first hypothesis is accepted, and the online consumer review variable (X2) has a significant and positive effect on the consumer loyalty variable. which means that the hypothesis is accepted,Also for simultaneous testing (Test F) there is a positive and significant effect, namely between the variable brand image and online consumer review on consumer loyalty Nature Republic aloe $92 \%$ soothing gel in Sukabumi City.

In testing R2 (Coefficient of Determination) produces a value of 0.516 which means that the brand image and online consumer review variables have a value of $51.6 \%$ and the remaining $48.4 \%$ is influenced.48.4\% influenced by other factors not examined in this study.

In this case, the brand image of a company or product is very important for the sustainability of its existence in the market, to be able to give or get consumer confidence in a company or product must have a good image that can be used as a benchmark for consumers to choose or buy a product that can fulfill their desires. as well as the needs of its consumers. And in online consumer reviews, companies must be able to find any mistakes or shortcomings of the products they sell and fix these so that consumers and existing customers do not move to competing companies

This study aims to re-examine the role of the variables of human capital, compensation, and work discipline on job satisfaction and employee performance. The results showed that human capital, compensation and work discipline had a significant and positive effect on job satisfaction and employee performance at the Central Bureau of Statistics of Aceh Province. A high level of job satisfaction can improve the relationship between human capital and compensation on employee performance, while not on the relationship between work discipline and employee performance. Human capital, compensation, and work 
discipline are important elements in increasing job satisfaction and employee performance.

The limitation of this research lies in the small number of samples used and the unit of analysis is only in the government sector. The variables used are transactional variables such as human capital, compensation, work discipline, satisfaction and performance. It is advisable for advanced researchers to use a large number of samples and expand their unit of analysis to the private sector. Regarding variables, it is better to use variables that are more transformational or contemporary, such as employee credibility and the role of information technology.

\section{REFERENSI}

Akmal Umar. 2011. Pengaruh Upah, Motivasi Kerja, dan Kepuasan Kerja terhadap Kinerja pekerja pada Industri Manufaktur di kota Makasar. Jurnal Aplikasi Manajemen, Volume 10, No. 2, ISSN: 1693-5241.

Alamsyah, Yunus. 2013. Pengaruh Disiplin Kerja, Motivasi, Kepemimpinan Terhadap Kepuasan Kerja Karyawan PT. Bumi Barito Utama cabang Banjarmasin, Jurnal Wawasan Manajemen, Vol. 1, No. 2.

Akmal, Akhwanul \& Tamini, Ihda. 2015. Pengaruh Kompensasi Terhadap Kepuasan Kerja Karyawan Gayamakmur Mobil Medan. Jurnal Bisnis Administrasi. Vol. 04, No. 02, 59-68.

Anoraga, Pandji. 2002. Psikologi Kerja. Jakarta: Rineka Cipta.

Arif Suroso \& Rotua Siahaan. (2006). Pengaruh Stres dalam Pekerjaan terhadap Kinerja Karyawan: Studi Kasus di Perusahaan Agribisnis PT. NIC. Jurnal Manajemen Agribisnis. Vol. III. No. 3.

Bachri, Naufal. 2018. Credibility-Profit Chain in Indonesian Islamic Banking Industry. Indian Journal of Public Health Research Development, 9(12),1951-1956.

Bachri, Naufal. 2019. Statistika Dasar untuk Bisnis: Teori, Pendekatan, dan Contoh Kasusnya. Sukabumi: CV Jejak.

Becker, Gary S. 2002. The Age of Human Capital, in E. P. Lazear: Education in the Twenty-First Century. Palo Alto: Hoover Institution Press, 3-8.

Chu, A. Z.-C., \& Chu, R. J.-C. 2011. The intranet's role in newcomer socialization in the hotel industry in Taiwan - technology acceptance model analysis. The International Journal of Human Resource Management, Vol. 22, No. 5 .

Davis, K.J.W \& Newstrom. 1994. Prilaku dalam Organisasi, Jilid I, Jakarta: Penerbit Erlangga

Fahmi, Irfan. 2014. Manajemen Keuangan Perusahaan dan Pasar Modal. Mitra Wacana Media. Jakarta.

Faturachman, Rovi. 2013. Human Capital Kompensasi dan Disiplin Kerja Terhadap Kinerja Karyawan. Jurnal Ilmu \& Riset Manajemen. Sekolah Tinggi Ilmu Ekonomi Indonesia (STIESIA): Surabaya.

Ghozali, Imam. 2014. Model Persamaan Struktural Konsep \& Aplikasi Dengan Program AMOS 22.0. (Edisi VI) Badan Penerbit Universitas Diponogoro: Semarang.

Gibson, Ivancevich, \& Donnely. 2003. Organisasi dan Manajemen: Perilaku Struktur. Erlangga: Jakarta.

Kadarisman. 2012. Manajemen Pengembangan Sumber Daya Manusia. PT. Raja Grafindo Persada, Jakarta.

Liyas, Jeli Nata \& Primadi, Reza. 2017. Pengaruh Disiplin Kerja Terhadap Kinerja Karyawan Pada Bank Perkreditan Rakyat. Al Masraf: Jurnal Lembaga Keuangan dan Perbankan. Vol. 2, No. 1, 17-26.

Hariandja, Marihot Tua Efendi. 2002. Manajemen Sumber Daya Manusia, Grasindo, Jakarta. 
Intergrative Human Capital Model: Emperical Evidence at the Central Statistics Agency in Aceh Province

Fitri Aswin ${ }^{1}$ Ichsan $^{2}$, Naufal Bachri ${ }^{3}$

Handoko, H. 2011. Manajemen Personalia dan Sumberdaya Manusia. BPFE. Yogyakarta.

Hasibuan, Malayu. 2013. Manajemen Sumber Daya Manusia. Jakarta: Bumi Aksara.

Humairoh. 2013. Analisis Pengaruh Budaya Organisasi Terhadap Kompenssasi Dengan Kepuasan Kerja Sebagai Variabel Intervening (Studi Kasus: Perusahaan Jasa Layanan Pelabuhan). Universitas Muhammadiyah Tangerang.

M Sahem, I Ichsan, \& N Bachri. 2021. Servant Leadership dan Kompetensi Komunikasi: Dampaknya terhdap Kepuasan dan Kinerja Pendamping Proram Keluarga Harapan (PKH) di Aceh Utara. Jurnal Manajemen Indonesia (J-MIND), 5(1), 32-47.

Mangkunegara, Prabu Anwar. 2012. Evaluasi Kinerja SDM Cetakan Keenam. Bandung: PT Refika Aditama.

Manullang. 2008. Dasar-Dasar Manajemen, Ghalia Indonesia (GI): Yogyakarta.

Martini \& Fadil. 2010. Perbedaan Tingkat Stres Akademik dan Strategi Pengelolaannya antara Siswa Program Akselerasi dengan Kelas Reguler. Bandung: Universitas Pendidikan Indonesia.

Mulyadi. 2012. Pengaruh Pemberian Kompensasi Terhadap Kinerja Karyawan pada PT. Balai Pustaka. Jurnal Economicus. STIE Pertiwi.

N Farmi, A Apridar, \& N Bachri. 2021. Pengaruh Quality of Work Life Terhadap Kinerja Karyawan PT. POS Indonesia (Persero) KPRK Lhokseumawe dengan Motivasi Intrinsik dan Kepuasan Kerja sebagai Variabel Intervening. Jurnal Manajemen Indonesia (J-MIND), 5(2), 84-93.

Nur, 2013. Pengaruh Komitmen Organisasi dan Komitmen Profesional Terhadap Kepuasan Kerja Auditor Dengan Motivasi Sebagai Variabel Intervening Survei Pada Kantor Akuntan Publik di Wilayah Surakarta dan DIY.

Ongkorahardjo Martina D.P. A., Antonius Susanto, \& Dyna Rachmawati. 2008. Analisis Pengaruh Human Capital Terhadap Kinerja Perusahaan (Studi Empiris pada Kantor Akuntan Publik Indonesia). Jurnal Akuntansi dan Keuangan, Vol. 10, No. 1.

Rachmawati. D., F. Wulani, \& C. E. Susilowati. 2004. Intellectual Capital dan Kinerja Bisnis: Studi Empiris pada Industri di Indonesia. International Management and Research Conference. Sanur Beach Bali Hotel, FEUniversitas Indonesia, Agustus: 1-21.

Rivai, Veithzal \& Sagala, Ella Jauvani. 2009. Manajemen Sumber Daya Manusia untuk Perusahaan. (Edisi kedua). Raja Grafindo Persada: Jakarta.

Rizal Yaya. 2016. Internet Financial Reporting dan Faktor-faktor yang Mempengaruhinya pada Pemerintah Kota dan Kabupaten di Indonesia. Jurnal Dinamika Akuntansi dan Bisnis. Vol. 3, No. 2, 89-104.

Rohimah. 2013. Pengaruh Kompetensi, Kompensasi, dan Kepuasan Kerja Terhadap Kinerja Karyawan pada PT. Ciomas Adisatwa Balikpapan. Jurnal Manajemen Sumber Daya Manusia.

Simamora, H. 2006. Manajemen Sumber Daya Manusia. Yogyakarta: STIE YKPN

Supriyanto. 2009. Metodologi Riset Bisnis, Indeks, Jakarta.

Suwatno, H \& Priansa, D.J. 2011. Manajemen SDM dalam Organisasi Publik dan Bisnis. Bandung : Alfabeta.

Y Yusrizal, AH Arifin, \& N Bachri. 2020. Pengaruh Komunikasi dan Gaya Kepemimpinan Terhadap Motivasi dan Kepuasan Kerja Pegawai Bakti pada Sekretariat DPRK Lhokseumawe. Jurnal Manajemen Indonesia (J-MIND), 4(1), 372-381.

Wahyudi, 2019. Pengaruh Disiplin Dan Motivasi Terhadap Kinerja Karyawan. SCIENTIFIC JOURNAL OF REFLECTION: Economic, Accounting, Management and Business. Vol. 2, No. 3, 351-360. 
Intergrative Human Capital Model: Emperical Evidence at the Central Statistics Agency in Aceh Province Fitri Aswin ${ }^{1}$, Ichsan ${ }^{2}$, Naufal Bachri ${ }^{3}$

Wanti. 2014. Pengaruh Kompensasi, Motivasi, dan Keahlian Terhadap Kinerja Karyawan (survei terhadap PT. PLN Persero di kecamatan sumberlawang). Universitas Muhammadiyah Surakarta.

Wibowo. 2007. Analisis Pengaruh Kompensasi dan Stres Kerja Terhadap Kinerja Karyawan CV. Lautan Rizki Group. Universitas Binus: Jakarta.

Yani, Devi.2016. Pengaruh Human Capital Dan Insentif Terhadap Kinerja Karyawan (Studi Kasus pada Rumah Sakit se-Kota Bandar Lampung). Jurnal Tesis Universitas Lampung: Bandar Lampung. 